\title{
Baku Baku Raja Traditional Game Model to Enhance Basic Movement Skills on Elementary Students in Indonesia
}

\author{
Hendriana Sri Rejeki ${ }^{1,2, *}$, Suharjana ${ }^{1}$, Wawan S. Suherman ${ }^{1}$, A. Ardiansyah ${ }^{3}$, Erif Ahdhianto ${ }^{4}$ \\ ${ }^{1}$ Department of Sport and Science, Yogyakarta State University, Indonesia \\ ${ }^{2}$ Department of Physical Education, Health and, Recreation, Universitas Tadulako, Indonesia \\ ${ }^{3}$ Department of Elementary Teacher Education, Institut Agama Islam Negeri Palu, Indonesia \\ ${ }^{4}$ Department of Elementary School Teacher Education, Universitas Nusantara PGRI Kediri, Indonesia
}

Received June 18, 2020; Revised August 17, 2020; Accepted August 28, 2020

\section{Cite This Paper in the following Citation Styles}

(a): [1] Hendriana Sri Rejeki, Suhardjana, Wawan S. Suherman, A. Ardiansyah, Erif Ahdhianto , "Baku Baku Raja Traditional Game Model to Enhance Basic Movement Skills on Elementary Students in Indonesia," Universal Journal of Educational Research, Vol. 8, No. 11, pp. 5158-5166, 2020. DOI: 10.13189/ujer.2020.081115.

(b): Hendriana Sri Rejeki, Suhardjana, Wawan S. Suherman, A. Ardiansyah, Erif Ahdhianto (2020). Baku Baku Raja Traditional Game Model to Enhance Basic Movement Skills on Elementary Students in Indonesia. Universal Journal of Educational Research, 8(11), 5158-5166. DOI: 10.13189/ujer.2020.081115.

Copyright $\odot 2020$ by authors, all rights reserved. Authors agree that this article remains permanently open access under the terms of the Creative Commons Attribution License 4.0 International License

\begin{abstract}
Enhancement in basic movement skills is a fundamental need for elementary school students in achieving the goals of physical education. The aim of this study was to produce a traditional game model called Baku Baku Raja to enhance Basic Movement skills on elementary students. Baku Baku Raja traditional game model has been adapted to the aspects of growth and development as well as the characteristics of children at their age, which are packaged through physical activities. This applied research and development method with product development steps by Borg and Gall. The research participants were 3rd-grade elementary school students in Palu, Indonesia. The results showed that the Baku Baku Raja traditional game model is feasible and effective in enhancing basic movement skills on elementary students. The researchers recommend that Baku Baku Raja traditional game model is used as an alternative for educators to optimize the success of student performance on not only psychomotor aspects but also cognitive and affective aspects.
\end{abstract}

Keywords Learning Model, Traditional Games, Basic Movement

\section{Introduction}

Physical education has the aim to help students enhance physical fitness and health through the introduction and inculcation of positive attitudes and basic physical abilities and various physical activities. Physical education is a study that analyzes associations. The goal of physical education can be achieved if education is carried out in schools properly [1]. Therefore, physical education provided in schools must conform the curriculum for physical education, sports, and health.

Physical education taught in schools has a very important role, i.e., to provide opportunities for educational participants to be directly involved in various learning experiences systematically - school physical education from time to time [2]. In line with contemporary theory, the relationship between the goals of the definition is more nuanced [3]. Physical education in schools is not just about educating through physical activities. Still, the process of learning about physical education is also used as one of the media to solve movement problems.

Physical education is the school program designed to lead youngsters to a lifetime of physical activity. Physical education sets its quality in guiding youngsters in the process of becoming physically active for a lifetime. Physical education is a school program designed to lead 
children to lifelong physical activity [4]. The goal of quality physical education is to guide children in the process of becoming physically active for a lifetime. Implementation of physical education in elementary school is significant because, at that age, a child is in a period of physical growth and develops movement skills that play an important role in early formation to become a quality individual later.

The traditional game in Central Sulawesi is a game that is done with motion, while in the game, children usually move to the left, sideways front and back. Baku Baku Raja traditional game is for children to do during school breaks and in the afternoon when children gather. The game is suitable for players is between 7-12 years [5].

Elementary school age is a period that determines the growth and physical development as well as the movement that plays an essential role in the formation of quality individuals in the future. The existing structure and curriculum of physical education in elementary schools that currently exist have characteristics that comprise the necessary technical skills of several sports. The primary technical skills of this sport can be mastered if the players have previously mastered basic movement skills. The basic movement skills in elementary schools can be divided into several categories, including three types, namely: locomotor, non-locomotor, and manipulation [6]. One of the objectives of the implementation of physical education, sports, and health in elementary schools is to enhance the ability and basic movement skills [7].

Human's basic movements are walking, running, jumping, and throwing [8]. Elementary school students have possessed this basic form of movement. Running and jumping are the basic movements that need to be developed in elementary school. The basic movement has an important role in learning physical education, especially sports that require movement of places or weight points such as sprinting, long jump, high jump, and other sports [9]. Elementary school students often experience obstacles or difficulties in participating in physical education learning that requires basic movement. In general, physical education learning in schools, including elementary schools, is based on actual skills or using real equipment. From the teaching of these skills, it turns out that elementary school students experience obstacles or difficulties because, in childhood, the basic ability of motion has just developed, so that physical education learning cannot be carried out optimally [10], [11]. For physical education learning, specifically, basic movement material to succeed, a conducive environment must be created, including modifying tools and creating learning models.

Basic motor skills can be applied in various games, sports, and physical activities that are carried out daily [12]. Through play activities, it is very appropriate to develop basic movement skills of children in elementary school, because basically, the world of children is the world of game [9]. Playing various forms of the game can be used by physical education teachers to form basic movement skills; one form of the game is a traditional sports game. Thus, the aim of this study is to produce a traditional game model of Baku Baku Raja to enhance the basic movement skills of elementary school students.

\section{Methods}

\subsection{Research Design}

This study developed the traditional game model of Baku Baku Raja to enhance the basic movement skills of elementary school students. The stages of developing the game model used research and development method that are adapted from the steps of Borg and Gall product development [13].

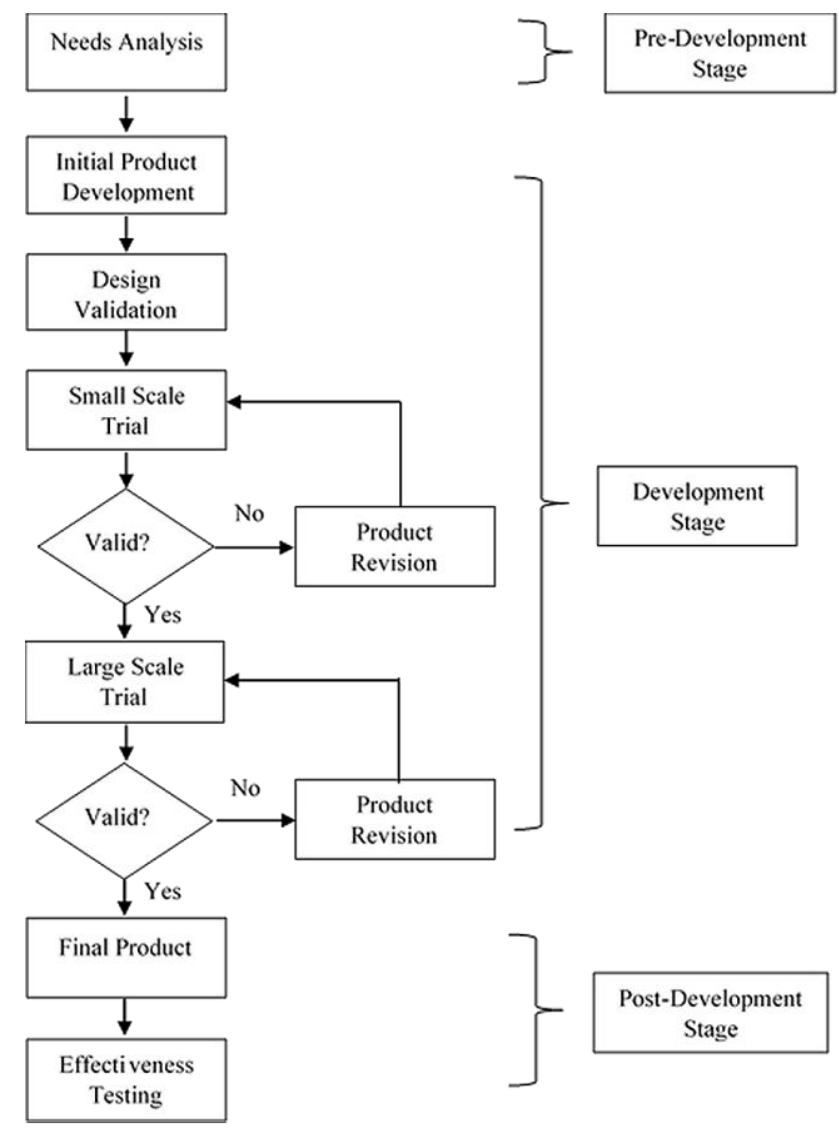

Figure 1. Research Stages Diagram

Figure 1 explains the three main stages of development consisting of the pre-development, development, and post-development stages. In the pre-development stage, the step taken is a needs analysis. Meanwhile, the development stage includes product design (initial product development), design validation, small-scale trials and revisions, and large-scale trials and revisions. Finally, the post-development stage includes the final product and 
effectiveness testing.

The effectiveness of the test in this study is used to test whether a final game model product that has been produced is feasible and has an advantage in the level of implementation in the field. The method used in this final product effectiveness test is an experiment.

The type of experiment used is pre-experimenting design, more specifically, a single group design with a pretest-posttest (one group pretest-posttest design) [14]. This type of experiment is carried out to compare conditions after being treated in the form of implementing a game model. The pre-experimental design used is as follows:

$$
\text { Pretest ------- > Treatment -------- > Posttest }
$$

Thus, the effectiveness of the use of game models developed in this study was known by analyzing the effect of the treated model. The effect was found out by comparing the results of motor skills before being given treatment with the results of motor skills, before being given treatment with the results after being treated.

\subsection{Research Participants}

The research participants were 3rd-grade elementary school students in the city of Palu, Indonesia. The purposive sampling technique was used to determine target participants as needed [14]. Research participants for the needs of small-scale trials were conducted at Kawatuna Elementary School, with a total of 33 students. Research participants for the needs of large-scale trials were conducted at Paboya Elementary School and Lasoani Elementary School, with a total of 55 students. Meanwhile, research participants for the needs of effectiveness test were conducted at Tanamodindi Elementary School and Lasoani Elementary School, with a total of 60 students.

\subsection{Data Collection Technique}

The collection techniques used were different depending on each stage of the development of the game model. Therefore, the instruments used were also different at each stage of development. In the pre-development stage, the instruments used were observation sheets and interview guidelines. The observation sheet had a category of observation, including learning time, teacher skills facilities, and infrastructures. It was used to observe the problems and needs directly. Meanwhile, interview guidelines were used to gather information through conversations with research participants.

In the development stage, the instrument used was a questionnaire and observation sheet-the questionnaire contained 23 items of statements regarding the categories of material content, construction, and language. The questionnaire was applied to assess game models by experts in physical education and practitioners, namely physical education teachers. Meanwhile, the observation sheet was used to determine the activity of basic movement skills during the implementation of the game model, which is also filled in by physical educators and practitioners. The results of validation by experts showed that the questionnaire and observation sheet had a Content Validity Index (CVI), namely 0.965 and 0.921 , respectively, with a Content Validity Ratio (CVR) of 0.00 , so this questionnaire was declared valid by the expert.

In the post-development stage, the instruments used were the Motor Skills Test (MST) and the questionnaire. The motor skills test was adapted from the Ulrich Test of Gross Motor Development-2 (TGMD-2) [15]. This test consisted of 12 test items that have two sub-variables categories, namely locomotor (run, gallop, hop, leap, horizontal jump, slide) and control objects (striking a stationary ball, stationary dribble, catch, kick, overhand throw and underhand roll). MST had been tested for validity and reliability by using Confirmatory Factor Analysis (CFA). Tests showed that the Goodness-of-Fit Index (GFI) was 0.96 and the Adjusted GFI (AGFI) was 0.95 . In addition, the reliability coefficient obtained in the locomotor sub-variable was 0.91 and the control object was 0.85 so that the MST was declared valid and reliable before use [16]. Meanwhile, the questionnaire was used to find out the students' responses after implementing the game model with 10 items of statements on aspects of pleasure, understanding, activity, and interest.

In this study, the implementation of game models in small- and large-scale trials was conducted during two meetings, respectively. The first meeting explained the game model and the second meeting to apply the game model. Meanwhile, in the effectiveness test, the game model is conducted for four meetings. The first and fourth meetings assess basic movement skills before and after the game model is applied, while the second and third meetings to explain and apply the game model, respectively.

\subsection{Data Analysis}

The data analyzed in this study consisted of qualitative data and quantitative data. The qualitative data were in the form of descriptive data obtained from the pre-development and development stages. This datum is in the form of descriptive words or sentences obtained from observations, interviews, and suggestions or input from the validators. This qualitative datum is analyzed by organizing data, describing it into units, synthesizing, arranging into patterns, choosing which are important and which will be studied, and making conclusions that can be conveyed to others [17].

Meanwhile, quantitative data were in the form of numerical data obtained from the development and post-development stages. This datum was obtained from 
questionnaires and MST. Data obtained from questionnaires were analyzed based on the categorization of the feasibility of the model, according to Azwar [18] (See Table 1).

Table 1. Guidelines for Converting the Score of Model Feasibility

\begin{tabular}{|c|c|c|}
\hline Formula & Interval & Category \\
\hline$X<(\mu-1,0 \sigma)$ & $X<7.7$ & Less \\
\hline$(\mu-1,0 \sigma) \leq X<((\mu-1,0 \sigma)$ & $7.7=X<15.3$ & Fair \\
\hline$((\mu-1,0 \sigma) \leq X$ & $15.3 \leq X$ & Good \\
\hline
\end{tabular}

Information :

$\mathrm{X}=$ Number of Participant Scores

$\mu=$ Ideal Mean

$=$ Number of items $\mathrm{x}$

$\sigma=$ standard ideal division

$=1 / 6[$ (number of items $\mathrm{x}$ highest score) - (number of items $\mathrm{x}$ lowest score )

On the other hand, data obtained from the administration of MST were analyzed by descriptive statistics and inferential statistics. Descriptive analysis was done by calculating the mean score and the score of students' motor skills gain before and after the game model was applied. Meanwhile, the inferential analysis was conducted using a t-test at the significance level of 5 percent. This test was intended to analyze the effectiveness of the implementation of the developed game model to students' motor skills.

In addition, data obtained from the administration of MST were tested for pre-requisites using tests of normality and homogeneity. The normality test was performed on the pretest data using the Chi-Square formula through SPSS 16.0 for Windows. Data were said to have normal distribution if significance $>0.05$. Conversely, if the significance $<0.05$, then the sample data were not normally distributed. Homogeneity tests were performed on pretest data in the control group and the experimental group. The homogeneity test calculation was also through the SPSS 16.0 for Windows program. The sample data were said to be homogeneous if the acquisition of significance $>0.05$. On the contrary, if the significance was $<0.05$, then the sample, data would be said as not homogeneous [14].

\section{Results and Discussion}

\subsection{Pre-development Stage}

\subsubsection{Need Analysis}

Based on the results of the analysis conducted in elementary schools, the following problems were obtained: (1) The form of basic movement learning for walking, running, jumping and throwing was less varied or monotonous; (2) The teacher was still confused in providing a form of game learning for grade III students with hours physical education, sports, and health learning that is long enough, which is $4 \times 35$ minutes; (3) The learning process was less effective in the use of time, which meant the learning process was not used optimally. This condition is proven by the excessive rest time used by students rather than doing the task of movement; (4) The compliance with the Learning Implementation Plan that teachers have made with the reality of practice; (5) Teacher creativity that has not been maximized, such as modifying tools used to support varied implementation games; (6) The ability of students to do basic movements was not optimal; (7) Students were less enthusiastic and lazy to follow the learning process and difficult to manage because the learning provided was less varied and monotonous.

Based on the needs analysis above, there must be a form of a game model with basic movement material that can accommodate the needs in the field, especially for physical education teachers based on the applicable curriculum objectives. The focus of development objectives includes (1) cognitive aspects seen from students' understanding of the rules of the game and the direction of the teacher, (2) affective aspects seen from students' social behavior such as responsibility, cooperation, and honesty, (3) psychomotor aspects that are seen from basic movement skills in the form of locomotor motion, non-locomotor motion, and manipulative movements.

\subsection{Development Stage}

\subsubsection{Initial Product Design}

The design of the game model developed includes aspects consisting of game illustration, preparation, equipment, game time, players, assessment, evaluation, and game procedure play [11].

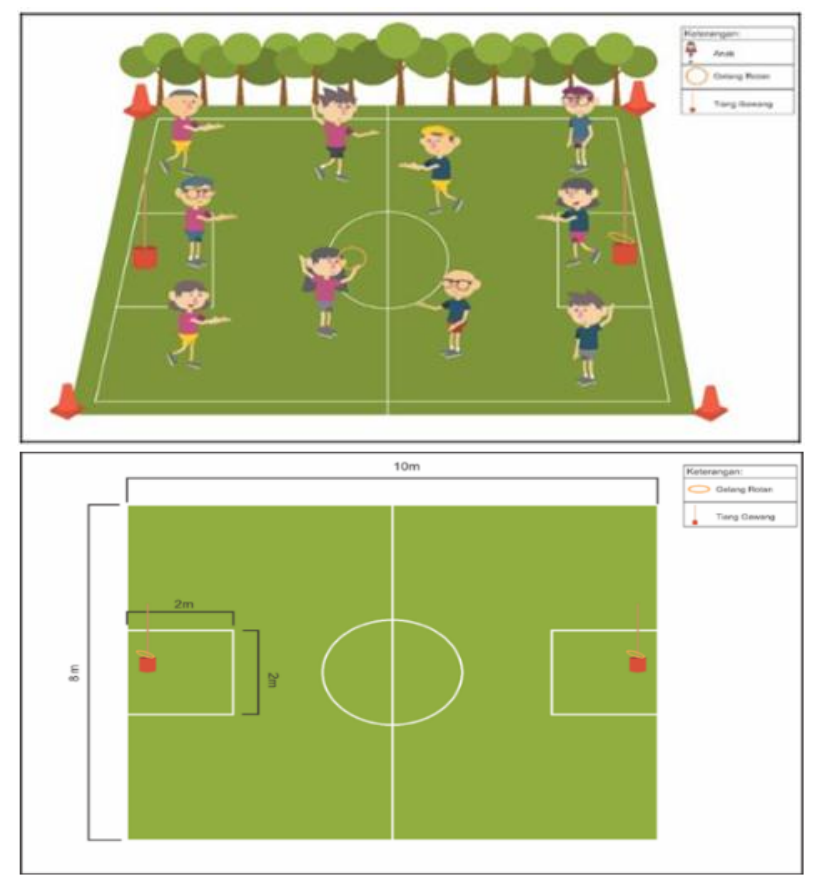

Figure 2. Baku Baku Raja Game Illustration 
The preparation aspects include preparing the playing field with a size of $6 \times 10$ meters (or a size adapted to the existing schoolyard) and preparing game equipment. The equipment prepared consisted of 1 piece of bracelet, two sticks as a goal post, ribbon, whistle, chalk, and meter. The time of the game is divided into two rounds with 15 minutes/round. Place exchanges take place in round II. Meanwhile, the players consist of 2 teams facing each other with the number of players adjusted to the size of the field, and one of the players each team being a stick/wicketkeeper and the other players play a role as an attacker.

Rating the game is based on each bracelet entered into the wicket with a score of one. The team that puts the most goals on the stick is considered as the winner. Meanwhile, the evaluation of the game carried out by the teacher must be to monitor the course of the game and supervise students not to leave the field area.

The game procedure consists of starting with (1) structuring the positions of two teams facing each other before starting; (2) Two players stand in the middle circle of the field facing each other then the referee throws the bracelet up between the two players for grabs; (3) Stick or goal keepers are in the guard area and may not come out and may not be replaced by attacking players; (4) the attacking player passes the bracelet to his friend or puts the bracelet on the goal stick by throwing; (5) The attacking player of each team tries to insert the bracelet into the goal stick; (6) Players who are holding a bracelet may not walk or run, but may only turn around or turn around with one foot as a footstool; (7) Players who do not hold the bracelet may move in any direction; (8) At the time of the game, the opposing player may not seize the bracelet that has been held, the opposing player must only obstruct an obstacle 1 metre away from the bracelet holder; (9) If the bracelet is thrown and there is a struggle, the person who has the right to hold the bracelet is the first person who has succeeded in capturing the bracelet; (10) If the bracelet comes out of the field, then the person who has the right to throw is the opposing player who last touched the bracelet; (11) foul occurs if a player pushes or drops an opponent intentionally. When a foul occurs, the bracelet is held by a team whose players have been violated; (12) violations also occur when the player holding the bracelet is walking or running while carrying the bracelet; (13) Goal occurs if the player succeeds in inserting the bracelet into the goal stick; (14) If there is a goal, then the game starts from the free area and the one holding the bracelet is the team who conceded; (15) The winning team is the team that places the most bracelets on the goal stick.

\subsubsection{Design Validation}

Experts and screenings further validated the initial design of the game model. Table 2 shows the results of the initial design validation of the game model by the experts.
Table 2. Frequency distribution judgment by experts

\begin{tabular}{|c|c|c|c|}
\hline \multirow{2}{*}{ Intervals } & E1 & E2 & E3 \\
\cline { 2 - 4 } & $\mathrm{F}$ & $\mathrm{f}$ & $\mathrm{F}$ \\
\hline $\mathrm{X}<7.7$ & 0 & 0 & 0 \\
\hline $7.7 \leq \mathrm{X}<15.3$ & 0 & 0 & 0 \\
\hline $15.3 \leq \mathrm{X}$ & 22 & 18 & 22 \\
\hline Total & 22 & 18 & 22 \\
\hline Mean & \multicolumn{3}{|c}{22} \\
\hline
\end{tabular}

As seen in the frequency distribution table above, each validator E1 (physical education expert), E2 (motoric expert), and E3 (motoric expert) gave scores of 22, 18, and 22. As a result, the mean score of the three validators was 20.67. Based on the established model eligibility categories, the initial design of the game model was declared good and valid for use [18].

Although the initial design of the game model was stated to be numerically valid, the initial design of the game model that was developed was enhanced based on the suggestions and input of the validators.

Table 3. The response of experts and revision

\begin{tabular}{|c|c|}
\hline Experts' Responses & Revisions \\
\hline $\begin{array}{c}\text { The size of the field for the } \\
\text { game Baku Baku Raja is } \\
\text { expanded so that children } \\
\text { can move freely }\end{array}$ & $\begin{array}{c}\text { The size of the field is enlarged } \\
\text { from } 6 \times 10 \mathrm{~m} \text { to } 8 \times 10 \text {, and the size } \\
\text { of the goalpost is raised from } 1 \times 1 \mathrm{~m} \\
\text { to } 2 \times 2 \mathrm{~m} .\end{array}$ \\
\hline $\begin{array}{c}\text { Learning objectives are more } \\
\text { specific }\end{array}$ & $\begin{array}{c}\text { The game Baku Baku Raja is } \\
\text { intended for learning basic } \\
\text { locomotor motion. }\end{array}$ \\
\hline $\begin{array}{c}\text { Game time allocation needs } \\
\text { to be enhanced }\end{array}$ & $\begin{array}{c}\text { The king's standard raw game from } \\
15 \text { minutes to 10 minutes }\end{array}$ \\
\hline
\end{tabular}

\subsubsection{Small-scale trials and revisions}

After obtaining the validation of the material experts to the initial draft of the game model, and having obtained qualifications worthy of being tested, the initial design of the model was tested on a small scale. The implementation of small-scale trials was recorded on DVD and then observed by validators consisting of experts and practitioners. Small-scale trials were conducted at Kawatuna Elementary School.

Table 4. Expert judgment on a small scale

\begin{tabular}{|c|c|c|c|c|}
\hline \multirow{2}{*}{ Intervals } & $\mathrm{E} 1$ & $\mathrm{E} 2$ & $\mathrm{E} 3$ & $\mathrm{P} 1$ \\
\cline { 2 - 5 } & $\mathrm{F}$ & $\mathrm{F}$ & $\mathrm{F}$ & 0 \\
\hline $\mathrm{X}<7.7$ & 0 & 0 & 0 & 0 \\
\hline $7.7 \leq \mathrm{X}<15.3$ & 0 & 0 & 0 & 0 \\
\hline $15.3 \leq \mathrm{X}$ & 22 & 22 & 22 & 23 \\
\hline Total & 22 & 22 & 22 & 23 \\
\hline Mean & \multicolumn{5}{|c|}{22.25} \\
\hline
\end{tabular}

Table 4 shows that validator E1 (physical education expert), E2 (motoric expert), E3 (motoric expert), and P1 (physical education teacher) gave scores of 22, 22, 22, and 23 , respectively. Hence, the mean score of the four 
validators is 22.25 . Based on the feasibility of the specified model, it is said that student activities during the implementation of the game model on a small scale are declared good [18].

Table 5. Results of a Small Scale Trial Student Questionnaire

\begin{tabular}{|c|c|c|c|c|}
\hline \multirow{2}{*}{ Statements } & \multicolumn{2}{|c|}{ Total } & \multicolumn{2}{c|}{$\%$} \\
\cline { 2 - 5 } & Yes & Not & Yes & Not \\
\hline $\begin{array}{c}\text { Are you able to do games that } \\
\text { are taught? }\end{array}$ & 33 & 0 & 100 & 0 \\
\hline $\begin{array}{c}\text { Do you understand the rules of } \\
\text { the game being taught? }\end{array}$ & 33 & 0 & 100 & 0 \\
\hline $\begin{array}{c}\text { Do you always obey the rules of } \\
\text { the game being taught? }\end{array}$ & 33 & 0 & 100 & 0 \\
\hline Is the game easy to do? & 31 & 2 & 93.55 & 6.45 \\
\hline $\begin{array}{c}\text { Do you like a tool that is used to } \\
\text { play? }\end{array}$ & 33 & 0 & 100 & 0 \\
\hline $\begin{array}{c}\text { Whether the game can help you } \\
\text { to learn the motion base jump? }\end{array}$ & 33 & 0 & 100 & 0 \\
\hline $\begin{array}{c}\text { Whether the game can help you } \\
\text { develop movement skills? }\end{array}$ & 33 & 0 & 100 & 0 \\
\hline Have fun games? & 33 & 0 & 100 & 0 \\
\hline $\begin{array}{c}\text { Do you dare to play the game } \\
\text { that is taught? }\end{array}$ & 30 & 3 & 90.32 & 9.68 \\
\hline $\begin{array}{c}\text { Do you want to repeat the game } \\
\text { being taught? }\end{array}$ & 33 & 0 & 100 & 0 \\
\hline Mean score & 32.5 & 0.56 & 98.39 & 1.6 \\
\hline
\end{tabular}

After implementing the game model on a small scale, students were given a questionnaire to find out the students' responses while running the game model. Table 5 shows that students have a response of $98.39 \%$ based on the score of the response category [17], Thus, the student's response were high to game models on a small scale. In other words, during the implementation of the game model on a small scale, students are motivated to move actively and do play activities with pleasure. Furthermore, the design of the game model was revised based on the suggestions and input of the validators while observing student activities during the implementation of the game model on a small scale.

Table 6. Expert responses and revisions on a small scale

\begin{tabular}{|c|c|}
\hline Experts' Responses & Revisions \\
\hline $\begin{array}{c}\text { There must be a differentiator } \\
\text { for each group A or B. }\end{array}$ & $\begin{array}{c}\text { Group A uses yellow shirts and } \\
\text { group B uses blue shirts }\end{array}$ \\
\hline $\begin{array}{c}\text { In the game the direction of the } \\
\text { goal is limited by the line }\end{array}$ & $\begin{array}{c}\text { The direction of the goal is } \\
\text { given a white line for the } \\
\text { marker }\end{array}$ \\
\hline $\begin{array}{c}\text { Raw Equipment Raw Raja is } \\
\text { made safe and attractive }\end{array}$ & $\begin{array}{c}\text { Goal treatment was made not } \\
\text { sharp, so it does not hurt } \\
\text { students and is colored so that } \\
\text { students are interested }\end{array}$ \\
\hline
\end{tabular}

\subsubsection{Large scale test trial and revision}

The steps taken in carrying out large-scale trials did not differ much from what was done at the time of small-scale trials. The difference only lies in the much higher number of test participants, test sites, and the implementation of expert and practitioner revision results to the game. The participants in the large-scale trial were conducted in Paboya Elementary School and Lasoani Elementary School.

Table 7. Expert judgment on a large scale

\begin{tabular}{|c|c|c|c|c|c|}
\hline \multirow{2}{*}{ Intervals } & $\mathrm{E} 1$ & $\mathrm{E} 2$ & $\mathrm{E} 3$ & $\mathrm{P} 1$ & $\mathrm{P} 2$ \\
\cline { 2 - 6 } & $\mathrm{F}$ & $\mathrm{F}$ & $\mathrm{F}$ & 0 & 0 \\
\hline $\mathrm{X}<7.7$ & 0 & 0 & 0 & 0 & 0 \\
\hline $7.7 \leq \mathrm{X}<15.3$ & 0 & 0 & 0 & 0 & 0 \\
\hline $15.3 \leq \mathrm{X}$ & 23 & 23 & 23 & 23 & 23 \\
\hline Total & 23 & 23 & 23 & 23 & 23 \\
\hline Mean & \multicolumn{5}{|l}{23} \\
\hline
\end{tabular}

Table 7 shows the mean score of the five validators consisting of validator E1 (physical education expert), E2 (motoric expert), E3 (motoric expert), P1 (physical education teacher), and P2 (physical education teacher) is 23. Based on the established model feasibility category, student activity during the implementation of the game model on a large scale was declared good [18].

Table 8. Large-scale trial student questionnaire results

\begin{tabular}{|c|c|c|c|c|}
\hline \multirow{2}{*}{ Statements } & \multicolumn{2}{|c|}{ Total } & \multicolumn{2}{c|}{$\%$} \\
\cline { 2 - 5 } & Yes & Not & Yes & Not \\
\hline $\begin{array}{c}\text { Are you able to do games that } \\
\text { are taught? }\end{array}$ & 52 & 3 & 94.82 & 5.18 \\
\hline $\begin{array}{c}\text { Do you understand the rules of } \\
\text { the game being taught? }\end{array}$ & 55 & 0 & 100 & 0 \\
\hline $\begin{array}{c}\text { Do you always obey the rules of } \\
\text { the game being taught? }\end{array}$ & 53 & 2 & 96.55 & 3.45 \\
\hline Do games easy to do? & 51 & 4 & 93.10 & 6.10 \\
\hline $\begin{array}{c}\text { Do you like a tool that is used to } \\
\text { play? }\end{array}$ & 53 & 2 & 96.55 & 3.45 \\
\hline $\begin{array}{c}\text { Whether the game can help you } \\
\text { to learn the motion base jump? }\end{array}$ & 55 & 0 & 100 & 0 \\
\hline $\begin{array}{c}\text { Whether the game can help you } \\
\text { develop movement skills? }\end{array}$ & 55 & 0 & 100 & 0 \\
\hline Have fun games? & 55 & 0 & 100 & 0 \\
\hline $\begin{array}{c}\text { Do you dare to play the game } \\
\text { that is taught? }\end{array}$ & 52 & 3 & 94.82 & 5.18 \\
\hline $\begin{array}{c}\text { Do you want to repeat the game } \\
\text { being taught? }\end{array}$ & 55 & 0 & 100 & 0 \\
\hline Mean score & 53.6 & 1.4 & 97.56 & 2.34 \\
\hline
\end{tabular}

After implementing the game model on a large scale, the students were given a questionnaire to determine the student's response while running the game model. Table 8 shows that students have a response of $97.56 \%$ based on the score of the response category [17]. Thus the student's response were high to game models on a large scale. In other words, during the implementation of the game model on a large scale, students are motivated to move actively and play with pleasure. At this stage, the game model design is not enhanced because the design is considered valid based on empirical evidence during the implementation of the game model on a large scale. 


\subsection{Post-development Stage}

\subsubsection{Final Product}

The final design of the Baku Baku Raja game model is as follows. The preparation aspect includes the preparation of a playing field with a size of $8 \times 15$ meters, or it can be adapted to the existing schoolyard and game equipment. The equipment consisted of 1 bracelet measuring $80 \mathrm{~cm}, 2$ sticks as a goal measuring $1.5 \mathrm{~m}, 20$ $\mathrm{cm}$ tape, a whistle, chalk, and a tape measure. The game is held in 2 rounds with a duration of 20 minutes/round, and a place is exchanged in the 2 nd round. Players are divided into 2 teams that face each other with the number of players according to the size of the field. One of the players in each team becomes the stick/goalkeeper, while the other players act as attackers.

The game evaluation is that each bracelet that goes to the goalpost gets a score of one, and the winning team is determined by the number of goals that enter the goalpost. Meanwhile, the teacher must monitor the course of the game and students should not get out of the field area.

The game procedure consists of: (1) Before the game starts, two groups face each other; (2) At the beginning of the game, two players stand in the middle of the field facing each other, then the referee throws the bracelet up between two players for a fight; (3) Keeper of the stick or goal must be in the area of the guard and must not come out. A stick keeper may not be replaced by an attacking player; (4) the attacking player passes his friend's wristband or throws the goalkeeper bracelet by throwing; (5) The attacking players of each team try to insert the goalpost bracelet; (6) The player holding the bracelet may not walk or run, may only turn or turn with one leg as a support; (7) The player not holding the bracelet may move in any direction; (8) During the game, the opposing player may not seize the bracelet that is already being held, the opposing player may only block the barrier within 1 metre from the bracelet holder; (9) If a bracelet is thrown and there is a seizure, then the person entitled to hold the bracelet is the first to catch the bracelet; (10) If the bracelet leaves the field the right to throw is the opposing player who last touched the bracelet; (11) Violations occur if a player pushes or drops an opponent intentionally; if a violation occurs, the bracelet is held by the team whose player was violated; (12) Violations also occur when the player holding the bracelet is walking or running while carrying the bracelet; (13) Goal occurs if the player succeeds in inserting the goal stick ring; (14) If a goal is scored then the play is started from the free area and the team that is the team conceding the bracelet is the team that is conceded; (15) The winning team is the team that has scored the most number of rings on the goal stick.

\subsubsection{Effectivity Test}

The final product from the development is a basic movement game model that can be used in physical education learning models in 3rd grade of elementary school, from the final product game model that has been produced, then the effectiveness test is conducted at Tanamodindi Elementary School and Lasoani.

Table 9. Students' basic movement skills in descriptive statistics

\begin{tabular}{|c|c|c|c|}
\hline \multirow{2}{*}{ Schools } & \multicolumn{2}{|c|}{ Mean score } & \multirow{2}{*}{ Gain } \\
\cline { 2 - 3 } & Pretest & Posttest & \\
\hline Tanamodindi & 50 & 70 & 0.40 \\
\hline Lasoani & 70 & 88 & 0,59 \\
\hline
\end{tabular}

Table 9 shows the mean grade of basic movement ability at Elementary School Tanamodindi for a pretest score of 50 and a posttest score of 70 with a gain score of 0.40 . Meanwhile, the mean score of the basic movement ability of Elementary School Lasoani for the pretest score was 70 , and the posttest score was 88 with a Gain score of 0.59 . Based on the category of model development results, the results of these pretest and posttest were in the medium category [18]. Furthermore, prior to inferential statistical testing, the data are pre-requisite testing through normality and homogeneity tests.

Table 10. Results of the normality test for basic movement skills

\begin{tabular}{|c|c|c|c|}
\hline \multirow{2}{*}{ Schools } & \multicolumn{2}{|c|}{ Sig. Score Normality } & \multirow{2}{*}{$\begin{array}{c}\text { Sig. Score } \\
\text { Homogeneity }\end{array}$} \\
\cline { 2 - 3 } & Pretest & Posttest & 0.236 \\
\hline Tanamodindi & 0.326 & 0.400 & 0.569 \\
\hline Lasoani & 0.107 & 0.285 & \\
\hline
\end{tabular}

Table 10 shows the score of pre-requisite testing through the normality test and homogeneity test. The obtained significance score of data normality in Tanamodindi Elementary School at pretest and posttest was 0.326 and 0.400 , respectively. Meanwhile, the significance score of data normality at Elementary School Lasoani at pretest and posttest was 0.107 and 0.285 , respectively. In addition, the significance score of homogeneity in Elementary School Tanamodindi and Elementary School Lasoani obtained from posttest data was 0.236 and 0.569 , respectively. Thus, based on the standard significance test pre-requisite [14]. The data in the form of basic movement abilities obtained from the two schools have been declared normal and homogeneous so that the data obtained from the game model are appropriate for inferential statistical analysis.

Table 11. Students' basic movement skills in inferential statistics

\begin{tabular}{|c|c|c|c|c|c|}
\hline Schools & Mean & $\mathbf{t}_{\text {count }}$ & Sig. & Dif. & $\%$ \\
\hline \multirow{2}{*}{ Tanamodindi } & 79.71 & \multirow{2}{*}{-17.37} & 0,000 & 11.04 & 13.5 \\
\cline { 2 - 6 } & 90.75 & & & & \\
\hline \multirow{2}{*}{ Lasoani } & 82.66 & \multirow{2}{*}{-25.30} & 0,000 & 10.71 & 12.9 \\
\cline { 2 - 5 } & 93.37 & & & \\
\hline
\end{tabular}

Table 11 shows the results of inferential statistical tests using the t-test. The test showed that the grades of 
Elementary School Tanamodindi and Elementary School Lasoani were -17.37 and -25.30 , respectively. The significance of the p-score was $<0.005$ [14] so that the game model was considered effective for enhancing basic movement skills di elementary school, especially for $3^{\text {rd }}$-grade.

\subsection{Discussion}

This study produces a standard Baku Raja traditional game model that is valid or suitable for use in elementary schools, especially at the third-grade level of elementary school. The main findings show that the implementation of the Baku Raja traditional game model is effective in enhancing basic movement skills on elementary students. Similar results of previous studies also show that games developed based on traditional perspectives will be able to effectively enhance student performance success in basic movement skills [11],[1],[19].

The success of student performance in basic movement skills shows that there is optimization in the psychomotor domain of students due to the association of other domains, namely cognitive and affective [9]. Cognitive domain associations are obtained when students obtain information in the form of the Baku Baku Raja traditional game model repeatedly. Meanwhile, the affective domain association is obtained when students do the traditional standard game Raja Baku together, which is cohesiveness and teamwork, as determining factors. This shows the similarity with Evan and Thondrike's sports learning theory that the principle in practicing sports is repetition. The more often the subject matter that is repeated, the more mastered it will be [20].

Another important finding is that the activities and responses of students to the Standard Baku Raja traditional game model are in a good category. In this study, the game model provides flexibility for students in their activities using all basic movement skills. During their activities, students are motivated to be active and play activities happily. Previous studies have shown that activity and response have a positive correlation in the implementation of a traditional game model [11],[21],[19]. Activity and motivation in sports are important for all students because of the associated benefits to physical, social, and psychological health [20],[19]. On the other hand, students' high motivation and activity in sports increase learning performance in cognitive, psychomotor, and affective aspects [20],[5],[10].

\section{Conclusions}

Based on the results and discussion of research, it can be concluded that Baku Baku Raja traditional game model developed is suitable for use. The implementation of this game model is effective in enhancing basic movement skills on elementary students, especially for $3^{\text {rd }}$-grade students. In addition, the implementation of the traditional game model has resulted in good student activity and motivation in sporting activities. Enhancing basic movement skills interprets the success of implementing the standard of Raja traditional game models not only in the psychomotor aspects but also in the cognitive and affective elements. Thus, Baku Baku Raja traditional game model developed is highly recommended for educators to enhance students' basic movement skills in elementary schools effectively.

\section{Acknowledgments}

Author thank to Research and Higher education Ministry of Indonesia for funding support in this study.

\section{REFERENCES}

[1] J. A. Kavanagh, J. Issartel, and K. Moran, "Quantifying Cycling as A Foundational Movement Skill in Early Childhood," J. Sci. Med. Sport, vol. 23, no. 2, pp. 171-175, 2020.

[2] A. Sameroff, "The Transactional Model," in The transactional Model of Development: How Children and Contexts Shape Each Other, A. Sameroff, Ed. American Psychological Association, 2009, pp. 3-21.

[3] A. J. Elliot, "A Conceptual History of the Achievement Goal Construct," in Handbook of competence and motivation, A. J. Elliot and C. S. Dweck, Eds. Guilford Publications, 2005, pp. 52-72.

[4] G. Graham, The Disordered Mind: An Introduction to Philosophy of Mind and Mental Illness. Canada: Routledge taylor \& Francis Group, 2010.

[5] R. E. Sulistyaningtyas and P. Y. Fauziah, "The Implementation of Traditional Games for Early Childhood Education," no. July, pp. 5-10, 2019.

[6] W. B. Strong, "Evidence Based Physical Activity for School-Age Youth," J. Pediatr., vol. 146, pp. 732-737, 2005.

[7] BNSP, Kurikulum Tingkat Satuan Pendidikan. Jakarta: Dirjen, 2006.

[8] A. Syarifuddin and M. Muhadi, Pendidikan Jasmani dan Kesehatan. Jakarta: Depdikbud, 1992.

[9] B. Hands and M. Martin, "Fundamental Movement Skills: Children's Perspectives," Australas. J. Early Child., vol. 28, no. 4, pp. 47-52, 2003.

[10] W. S. Suherman, Dapan, Guntur, and N. R. Muktiani, "Development of Traditional Children Play Based Instructional Model to Optimize Development of Kindergarteners' Fundamental Motor Skill," Cakrawala Pendidik., vol. 38, no. 2, pp. 356-365, 2019. 
[11] M. F. Amir, I. A. Mufarikhah, A. Wahyuni, Nasrun, and H. E. Rudyanto, 'Developing 'Fort Defending' Game as a Learning Design for Mathematical Literacy Integrated to Primary School Curriculum in Indonesia," Elem. Educ. Online, vol. 18, no. 3, pp. 1081-1092, 2019.

[12] R. Lutan, Asas-Asas Pendidikan Jasmani. Jakarta: Depdikbud, 2001.

[13] W. R. Borg and M. D. Gall, Educational Research An Introduction. New York: Longman Publisher, 1983.

[14] J. W. Creswell and T. C. Guetterman, Educational Research: Planning, Conducting, and Evaluating Quantitative and Qualitative Research, 6th Edition. Boston, United States of America: Pearson Education, 2018.

[15] D. A. Ulrich, Test of Gross Motor Development. Austin, TX: Pro-ed Publishers, 2000.

[16] K. Y. A. Wong and S. Y. Cheung, "Confirmatory Factor Analysis of Test of Gross Motor Development-2," J. Meas. Phys. Educ. Exerc. Sci., vol. 14, pp. 202-209, 2010.

[17] Sugiyono, Metode Penelitian Kuantitatif, kualitatif dan $R$ \&
D. Bandung: Alfabeta, 2013.

[18] S. Azwar, Metode Penelitian. Yogyakarta: Pustaka Pelajar, 2003.

[19] K. Gjicali, B. M. Finn, and D. Hebert, "Effects of Belief Generation on Social Exploration, Culturally-Appropriate Actions, and Cross-Cultural Concept Learning in A Game-Based Social Simulation," Comput. Educ., vol. 156, no. March, p. 103959, 2020.

[20] J. Evans and A. S. Thorndike, Quantum Mechanics at The Crossroads, New Perspectives from History, Philosophy and Physics, The Fronti. Springer, 2010.

[21] J. L. Nietfeld, "Predicting Transfer from A Game-Based Learning Environment," Comput. Educ., vol. 146, p. 103780 , 2020.

[22] A. Johnstone, A. R. Hughes, X. Janssen, and J. J. Reilly, "Pragmatic evaluation of the Go2Play Active Play Intervention on Physical Activity and Fundamental Movement Skills in Children," Prev. Med. Reports, vol. 7, pp. 58-63, 2017. 